\title{
CURRENT
}

\section{MEKANISME GOOD CORPORATE GOVERNANCE DAN DEWAN PENGAWAS SYARIAH PADA KINERJA KEUANGAN PERBANKAN SYARIAH INDONESIA}

\author{
Anthon Indra Jaya ${ }^{1^{*}}$, M. Rasuli ${ }^{2}$ \\ ${ }^{123}$ Program Studi Akuntansi, Fakultas Ekonomi dan Bisnis, Universitas Riau, Pekanbaru \\ *E-mail: anthondrajaya@gmail.com
}

\begin{tabular}{l}
\hline Keywords \\
\hline Audit Committee, Risk \\
Monitoring Committee, \\
Remuneration and \\
Nomination Committee \\
\hline
\end{tabular}

Article Information

Received:

2020-07-30

Accepted:

2020-02-19

Available online:

2020-03-26

\begin{abstract}
This study aims to discuss and analyze about how the mechanism internal of good corporate governance such as: Effect of audit committe effectiveness on the performance of sharia banking, Effect of risk monitoring committee effectiveness on sharia banking performance, Effect of remuneration and nomination committee effectiveness on sharia banking performance, and also sharia supervisorsboard effectiveness on sharia banking performance in Indonesian between 2014-2018. The data used in this study are secondary data by measuring the number of meetings taken from each variable. The method used in sample selection is purposive sampling. The number of samples in this study were 12 banks taken from the annual report with 60 samples. The hypothesis test used in this study is the statistical t test. The data analysis technique used in this study is multiple linear analysis using statistical products and service solutions (SPSS) version 20.0. The results of the study showed that the effectiveness of audit committee, risk monitoring committee, nomination and remuneration committee, and sharia supervisory board had a positive effect on the financial performance of sharia banking.
\end{abstract}

\section{PENDAHULUAN}

Sebuah perusahaan yang mampu menjalankan operasionalnya secara efektif dan efesien menggambarkan kemampuan perusahaan tersebut dalam melaksanakan tata kelola yang baik. Tata kelola yang baik dikenal dengan Good Corporate Governance. "Corporate Governance merupakan susunan aturan yang menentukan hubungan antara pemegang saham, manajer, kreditor, pemerintah, karyawan dan stakeholder internal dan eksternal yang lain sesuai dengan hak dan tanggungjawabnya" (FCGI, 2003). Dengan adanya sistem Corporate Governance dapat memberikan keyakinan kepada para pemegang saham dan investor ata atas investasi yang dilakukan dalam suatu perusahaan dalam rangka kemampuan memperoleh return yang diharapkan. Corporate Governance akan dapat memberikan perlindungan bagi kepentingan para pemegang saham dan investor. Corporate Governance juga dapat 
membantu dalam menciptakan lingkungan yang kondusif melalui fungsi pengawasan demi terciptanya pertumbuhan yang efisien dan efektif dalam perusahaan.

Corporate Governance yang efisien dan efektif dapat dilihat pada bagaimana mekanisnya dijalankan. Mekanisme ini merupakan suatu peraturan, prosedur dan menggambarkan hubungan antara pihak pengambil keputusan dengan pihak yang melakukan pengendalian terhadap keputusan tersebut. Rezaee membagi mekanisme GCG menjadi dua yaitu mekanisme internal dan mekanisme external (Rezaee. 2009). Mekanisme internal seperti dewan komisaris dengan komite-komitenya yaitu komite audit, komite pemantau resiko, komite remunerasi dan nominasi. Sementara mekanisme eksternal seperti peraturan pemerintah, kantor akuntan public, dll. Mekanisme GCG ini berperan sebagai bagian menyeluruh dari suatu perusahaan yang mampu mempengaruhi kinerja perusahaan.

Adapun kinerja yang dimaksud disini adalah kinerja keuangan. Kinerja keuangan memiliki kaitan yang erat dengan prediksi atau proyeksi tentang pertumbuhan (growth) perusahaan. Sehingga data kinerja keuangan mampu membantu manajemen dalam merumuskan bagaimana perusahaan ke depannya. "Kinerja keuangan adalah hasil atau prestasi yang telah dicapai oleh manajemen perusahaan dalam mengelola aset perusahaan secara efektif selama periode tertentu, kinerja keuangan sangat dibutuhkan oleh perusahaan untuk mengetahui dan mengevaluasi tingkat keberhasilan perusahaan berdasarkan aktivitas keuangan yang telah dilaksanakan, Rudianto (2013)". "Kinerja keuangan adalah gambaran tentang keberhasilan perusahaan berupa hasil yang telah dicapai berkat berbagai aktivitas yang telah dilakukan. Kinerja keuangan merupakan suatu analisis untuk menilai sejauh mana suatu perusahaan telah melaksanakan aktivitas sesuai aturan pelaksanaan keuangan (Fahmi, 2012)". Kinerja keuangan merupakan penilaian kinerja tentang sehat atau tidaknya suatu perusahaan dengan memperhitungkan rasio-rasio keuangan perusahaan. Salah satu rasio yang dapat digunakan untuk menilai dan mengevaluasi kinerja keuangan perusahaan adalah rasio profitabilitas yaitu Return On Asset (ROA) (Kasmir, 2016). Melalui ROA memberi gambaran bahwa kemampuan asset yang dikelola dengan efektif dan efisien maka akan memberikan dampak kepada kinerja berupa return dalam bentuk laba yang diharapkan. Oleh karena itu, suatu perusahaan harus mempunyai target anggaran dan mampu mencapai target tersebut dalam satu tahun anggaran yang ditetapkan. Tercapainya laba atau semakin meningkat laba yang diperoleh menandakan bahwa kinerja perusahaan mengalami peningkatan.

Selanjutnya berbicara mengenai kinerja perbankan Syariah, sama halnya seperti bank umum yaitu kinerja bank Syariah diukur melalui indikator keuangan yang diatur oleh Bank Indonesia dan Otoritas Jasa Keuangan. Termasuk menggunakan rasio Return On Asset (ROA). 
Akhir-akhir ini kinerja keuangan bank menjadi sorotan karena walau asset sudah di atas 5\% asset perbankan nasional namun tingkat kesehatan dan kinerja dari bank syariah secara umum di Indoensia masih munjukkan masalah. Seperti terjadinya fraud di beberapa bank syariah (kompasiana.com, 2019), kredit macet di Bank Muamalat dan penyimpangan ketaatan pada aturan bank lainnya. Kinerja perbankan syariah di tanah air sepanjang sembilan bulan tahun 2019 cenderung semakin melemah, terimbas oleh kondisi ketidakstabilan ekonomi global dan domestik (finansial.bisnis.com, 2019). Fenomena yang terjadi dapat dikatakan bahwa kinerja pada perbankan syariah mengalami performance yang menurun secara menyeluruh Hal ini menunjukkan kepada lemahnya penerapan tata kelola perusahaan yang baik (Good Corporate Governance) pada bank-bank tersebut.

Dengan kondisi perbankan syariah saat ini menarik penulis untuk mengkaji lebih dalam hubungan penerapan Good Corporate Governance dengan kinerja bank syariah. Pengukuran kinerja bank syariah dilakukan berdasarkan kepada "Peraturan Otoritas Jasa Keuangan Nomor 8/POJK.03/2014 tentang Penilaian Tingkat Kesehatan Bank Umum syariah dan Unit Usaha Syariah”. Adapun faktor yang menjadi penilaian tingkat kesehatan bank untuk bank umum syariah adalah profil risiko (risk profile), good corporate governance, rentabilitas (earnings), dan permodalan (capital). Sedangkan, untuk Unit Usaha Syariah faktor yang menjadi penilaian tingkat kesehatan bank hanya faktor profil risiko (risk profile).

Mekanisme GCG yang hendak menjadi perhatian adalah mekanisme internal, yaitu berkaitan dengan pelaksanaan tugas dewan komisaris yakni agar dapat menjalankan pengawasan dengan efektif. Sesuai dengan Peraturan "Otoritas Jasa Keuangan (POJK) No 55, 2016, maka dewan komisaris suatu perusahaan wajib membentuk komite-komite guna membantu tugasnya, paling sedikit komite berikut ini: komite audit, komite pemantau resiko dan komite remunerasi dan nominasi”.

Komite audit yang beranggotakan satu atau lebih anggota dewan komisaris independen. Dewan komisaris dapat meminta kalangan luar perusahaan dari berbagai keahlian, pengalaman dan kualifikasi lain yang dibutuhkan, untuk duduk sebagai anggota komite audit guna mencapai tujuan peran komite audit. (Komite Nasional Kebijakan Corporate Governance, 2000).

Beberapa penelitian sebelumnya cukup banyak yang meneliti komite audit sebagai variabel independen dalam kaitan dengan kinerja. Penelitian terdahulu, Hartono dan Nugrahanti (2014), Sulistyowati dan Fidiana (2017) meneliti bahwa komite audit tidak berpengaruh terhadap kinerja keuangan. Berbeda pula penelititan Arifani (2013), Hisamuddin dan Tirta (2011) juga menghasilkan ukuran komite audit berpengaruh dengan kinerja. 
Merujuk pada "Peraturan Bank Indonesia Nomor 11/33/PBI/2009 tentang Pelaksanaan Good Corporate pada Bank Umum Syariah dan Unit Usaha Syariah, bahwa Komite Pemantau Risiko adalah komite yang dibentuk oleh dan bertanggung jawab kepada Dewan Komisaris dalam usaha mendukung pelaksanaan tugas dan tanggung jawab Dewan Komisaris terkait penerapan dan pengawasan manajemen risiko pada perusahaan. Pada beberapa jenis usaha di Indonesia, seperti perbankan dan Lembaga Pembiayaan Ekspor Indonesia (LPEI), keberadaan Komite Pemantau Risiko dalam struktur organisasi telah diwajibkan berdasarkan beragam peraturan yang ditetapkan pihak regulator terkait". Hubungan antara komite pemantau resiko terhadap kinerja perbankan pernah diteliti oleh Widyani (2015) yang menyatakan bahwa komite pemantau resiko memiliki hubungan positif terhadap kinerja keuangan perbankan. Namun Hutami (2014) menunjukkan hasil penelitian berbeda, yaitu komite pemantau resiko tidak memiliki hubungan signifikan terhadap kinerja perbankan.

Selanjutnya "POJK Nomor 59 (2017) khusus remunerasi dan nominasi di bank syariah yaitu POJK Tentang Penerapan Tata Kelola Dalam Pemberian Remunerasi Bagi Bank Umum Syariah Dan Unit Usaha Syariah mewajibkan pembentukan Komite Remunerasi dan Nominasi oleh Dewan komisaris. Peraturan mengenai keberadaan Komite Nominasi dan Renumerasi secara eksplisit disebutkan dalam Peraturan Bank Indonesia sehingga keberadaan komite tersebut sangat terasa di industri perbankan termasuk di bank syariah baik status bank umum mapun masih Unit Usaha Syariah (UUS). Komite remunerasi dan nominasi juga terdapat dalam perusahaan industri non-perbankan dan lebih bersifat voluntarily dari pada regulatory."

Penelitian-penelitian terdahulu terkait pengaruh komite remunerasi terhadap kinerja perusahaan masih menunjukkan hasil yang belum konsiten. Setyawati dan Ataina Hudayati, (2019), Zakaria (2018) melakukan penelitian tentang hubungan antara komite remunerasi dan kinerja keuangan perbankan komite remunerasi, peraturan Otoritas Jasa Keuangan dan nominasi idak berpengaruh signifikan terhadap kinerja perusahaan. Mekanisme internal yang membedakan bank syariah dengan konvensional adalah adanya dewan pengawas syariah (DPS). "Peraturan Bank Indonesia PBI No. 11/33/PBI/2009 tentang pelaksanaan good coorporate governance bagi bank umum syariah dan unit usaha syariah menguraikan tugas, wewenang, dan tanggung jawab suatu badan yang memiliki peran penting yaitu Dewan Pengawas Syariah (DPS). Memiliki tugas memastikan dan mengawasi kesesuaian kegiatan operasional bank terhadap fatwa yang dikeluarkan DSN”. Menilai aspek syariah terhadap pedoman operasional dan produk yang dikeluarkan bank. Memberikan opini dari aspek syariah terhadap pelaksanaan operasional bank secara keseluruhan dalam laporan publikasi bank. Mengkaji produk dan jasa baru yang belum ada fatwa untuk dimintakan fatwa kepada DSN. 
Penelitian Erfina (2014) tentang pengaruh Good Corporate Governance (GCG) terhadap kinerja keuangan mengungkapkan variabel dewan pengawas syariah tidak memiliki pengaruh signifikan terhadap kinerja keuangan. Sementara Hisamuddin dan Tirta (2011) meneliti pengaruh Good Corporate Governance terhadap kinerja keuangan bank umum syariah menunjukkan ukuran Dewan Pengawas Syariah berpengaruh terhadap kinerja keuangan uang diproksikan dengan ROA dan ROE.

Dari beberapa penelitian yang telah dilakukan tersebut dapat disimpulkan bahwa pengaruh dari masing-masing struktur atau organ dalam mewujudkan GCG terhadap kinerja keuangan masih menunjukkan hasil yang belum konsisten. Sehingga penelitian ini memfokuskan pada penerapan GCG dengan proporsi mekanisme dewan komisaris independen dan proksi Dewan Pengawas Syariah dengan objek penelitian perbankan syariah di Indonesia.

Peneliti termotivasi untuk melakukan penelitian dengan melihat kepada efektivitas masing masing variabel dalam menjalankan fungsi masing-masing. Hal ini dilakukan oleh masing-masing variabel dalam mengawasi jalannya operasional perusahaan membantu tugas dari dewan komisaris. Pengawasan tersebut dilakukan dalam bentuk salah satunya adalah melakukan pertemuan atau rapat guna membahas dan memberikan masukan kepada manajemen sebagai bagian dari laporan tata kelola perusahaan yang telah diatur oleh regulator. Sehingga efektivitas masing-masing variabel akan tampak memberikan pengaruh kepada manajemen untuk selanjutnya memperbaiki kinerja manajemen terutama dalam mengelola aset yang berujung kepada tingkat return yang diharapkan.

Berdasarkan uraian di atas, maka penelitian ini diberi judul "Pengaruh Mekanisme Good Corporate Governance dan Dewan Pengawas Syariah Terhadap Kinerja Keuangan Perbankan Indonesia".

\section{PENGEMBANGAN HIPOTESIS}

\section{Pengaruh Komite Audit terhadap Kinerja Keuangan}

Keberadaan komite audit merupakan salah satu unsur dalam konsep good corporate governance yang diharapkan mampu memberikan kontribusi terbaik dalam level penerapannya. Komite audit diharapkan mampu meningkatkan kualitas pengawasan internal, yang pada akhirnya ditujukan untuk memberikan perlindungan yang maksimal kepada para pemegang saham dan stakeholder lainnya. Salah satu tugas dan tanggung jawab komite audit adalah melakukan penelaahan atas informasi keuangan yang dikeluarkan perusahaan seperti laporan keuangan, proyeksi dan informasi keuangan lainnya. 
Dalam melakukan penelaahan atas informasi keuangan yang dikeluarkan perusahaan, komite audit perlu memperhatikan penelaahan kebijakan akuntansi, penelitian laporan keuangan interim dan laporan keuangan tahunan, laporan manajemen dan opini auditor atas laporan keuangan. Penyajian laporan keuangan yang berkualitas dapat meminimalkan konflik kepentingan antara pemegang saham pengendali dengan pemegang saham minoritas. Dengan demikian, komite audit dapat meminimalkan biaya keagenan dengan penyajian informasi akuntansi yang berkualitas kepada para stakeholder (Nur DP, 2012).

Berdasarkan "POJK No. 55 tahun 2016 salah tugas dan tanggung jawab komite audit adalah wajib melakukan pemantauan dan evaluasi atas perencanaan dan pelaksanaan audit serta pemantauan atas tindak lanjut hasil audit dalam rangka menilai kecukupan pengendalian intern, termasuk kecukupan proses pelaporan keuangan”. Pelaksanaan tugas dengan efektif dan efisien akan memberikan dampak kepada manajemen, apakah itu dari jumlah anggota komite, jumlah pertemuan komite maupun interaksi dengan dewan komisaris untuk selanjutnya menjadi perhatian bagi manajemen perusahaan.

Penelitian sebelumnya dilakukan Arifani (2013) yang menyatakan bahwa komite audit memiliki pengaruh terhadap kinerja keuangan. Sementara penelitian Lestari dan Asyik (2015) menghasilkan bahwa hubungan antara komite audit dengan kinerja keuangan tidak berpengaruh.

\section{$\mathrm{H}_{1}$ : Komite Audit berpengaruh terhadap kinerja keuangan.}

\section{Pengaruh Komite Pemantau Resiko Terhadap Kinerja Keuangan}

Komite pemantau resiko adalah komite yang dibentuk untuk mendukung efektivitas tugas dan tangggung jawab dewan komisaris. Karena suatu perusahaan apalagi lembaga keuangan pasti memiliki resiko-resiko yang mungkin terjadi. Munculnya resiko-resiko ini tidak bisa dihindari. Oleh karena itu, resiko yang muncul itu dikelola dengan meminimalisir kemungkinannya terjadi. Jika mampu dikelola dengan efektif dan efisien maka dapat berkontribusi pada perusahaan.

Kemudian guna mengelola resiko maka industri perbankan telah menyiapkan upaya tata kelola yang baik yaitu setiap entitas melalui Dewan Komisaris wajib membentuk komite. Dalam hal ini komite itu adalah Komite Pemantau Resiko. POJK No. 55 tahun 2016 mengatur setidaknya tugas komite ini yakni: evaluasi tentang kesesuaian antara kebijakan manajemen risiko dengan pelaksanaan kebijakan bank, pemantauan dan evaluasi pelaksanaan tugas komite manajemen risiko dan satuan kerja manajemen risiko, guna memberikan rekomendasi kepada dewan komisaris. 
Sebagai bagian dari dewan komisaris, komite pemantau resiko berperan penting dalam meningkatkan kinerja keuangan suatu perusahaan. Pengawasan resiko yang tidak baik akan mempengaruhi jalannya perusahaan. Dalam hal ini faktor jumlah anggota komite ataupun jumlah rapat yang dijalankan memungkin memberi pengaruh kepada kemampuan monitoring terhadap resiko yang dihadapi oleh suatu perusahaan.

Penelitian terkait hubungan antara komite pemantau resiko dengan kinerja keuangan dilakukan oleh Hutami dan Marsono (2014) memiliki hubungan positif terhadap kinerja keuangan yang diproksi dengan NIM dengan LDR dan negatif tetapi tidak signifikan terhadap kinerja yang diproksi dengan CAR. Namun hasil penelitian (Widyani, 2015) komite pemantau resiko berpengaruh signifikan terhadap kinerja Bank Pembangunan Daerah di Indonesia.

\section{$\mathrm{H}_{2}$ : Komite Pemantau Resiko berpengaruh terhadap Kinerja Keuangan.}

\section{Pengaruh Komite Remunasi dan Nominasi terhadap Kinerja Keuangan}

"Komite remunerasi merupakan salah satu organ perusahaan yang mendukung kerja dewan komisaris dalam membantu melaksanakan fungsi dan tugas dewan komisaris terkait remunerasi terhadap anggota direksi dan anggota dewan komisaris. Remunerasi eksekutif yang tepat harus bertujuan untuk menjamin keselarasan kepentingan antara eksekutif dan pemegang saham untuk mencapai tujuan perusahaan yaitu nilai perusahaan. Nilai perusahaan terlihat dari kinerja perusahaan yang baik". Efektivitas komite remunerasi dapat dilihat dari berbagai aspek, peraturan "OJK 59/POJK.03/2017 menetapkan fungsi, tugas dan tanggung jawab komite remunerasi pada bank syariah, diantaranya menguraikan bahwa keanggotaan komite remunerasi paling kurang terdiri dari 3 (tiga) orang anggota. Diharapkan dengan terpenuhinya ketentuan jumlah anggota komite remunerasi, tugas dan tanggung jawab dewan komisaris dapat dijalankan dengan baik dan seiring dengan hal tersebut kinerja perusahaan juga menjadi lebih baik".

Kedudukan komite audit dan komite remunerasi sebagai organ perusahaan yaitu mendukung kerja dewan komisaris dalam membantu melaksanakan fungsi dan tugas dewan komisaris. Widyani (2015) mengungkapkan bahwa komite remunerasi dan nominasi memiliki pengaruh terhadap kinerja perusahaan.

\section{$\mathrm{H}_{3}$ : Komite Remunerasi dan Nominasi berpengaruh terhadap Kinerja Keuangan.}

\section{Pengaruh Dewan Pengawas Syariah terhadap Kinerja Keuangan}

Salah satu kegiatan rapat Dewan Pengawas Syariah (DPS) adalah memberikan opiniopini mengenai semua kegiatan operasional, produk dan penyaluran dana termasuk mengawasi kegiatan menyalurkan dana zakat, infak, sedekah dan wakaf yang bisa diakui sebagai bentuk Islamic Social Reporting (ISR) perusahaan. 
DPS bertugas dalam mengawasi operasional bank dan memberi nasehat kepada direksi agar dapat memperoleh kinerja keuangan sesuai dengan prinsip syariah. Salah satu bentuk aplikasi dari penerapan tugas tersebut adalah dengan menyelengaraan rapat. Pelaksanaan rapat DPS dipersyaratkan dalam PBI No.11/33/PBI/2009 dan SEBI No.12/13/DPbS tentang Pelaksanaan GCG Bagi Bank Umum Syariah (BUS) dan Unit Usaha Syariah (UUS) mengatur bahwa rapat DPS diselenggarakan minimal sekali dalam 1 (satu) bulan. Menurut Hisamuddin dan Tirta (2011) menyatakan bahwa Dewan Pengawas Syariah berpengaruh signifikan terhadap kinerja. Hal ini bermakna makin besar aktifitas DPS (jumlah anggota dan jumlah rapat) maka kemungkinan monitoring manajemen perusahaan terhadap ketaatan pada penerapan prinsip syariah akan semakin baik, sehingga juga bisa menekan terjadinya penyimpangan dalam aktivitas yang tidak berprinsip syariah yang dapat berakibat mengurangi profitabilitas. Dewan Pengawas Syariah diukur dengan jumlah rapat pengawas di dalam perusahaan (Purwanti, 2016).

\section{H4: Dewan Pengawas Syariah berpengaruh terhadap Kinerja Keuangan.}

\section{METODE PENELITIAN}

\section{Sumber Data}

Data yang digunakan dalam penelitian ini adalah data sekunder yaitu data yang diperoleh dari annual report yang diterbitkan oleh perusahaan-perusahaan perbankan syariah yang dilihat statistik perbankan syariah yang dikeluarkan oleh OJK pada desember tahun 2014-2018.

\section{Populasi dan Sampel}

Populasi dari penelitian ini adalah semua bank umum syariah di Indonesia periode 20142018 yaitu 14 perusahaan. Dari jumlah tersebut diperoleh sampel berjumlah sebanyak 12 perusahaan.

\section{Teknik Pengumpulan Data}

Metode pengumpulan data yang digunakan dalam penelitian ini adalah metode dokumentasi yaitu data yang diperoleh dari resmi masing masing website perusahaan, website regulator dan otoritas, dari jurnal, artikel, tesis dan literatur lainnya yang berkaitan dengan penelitian.

\section{Definisi Operasional dan Pengukuran Variabel}

Kinerja Keuangan Perbankan di penelitian ini menggunakan instrumen yang dikembangkan oleh Fauzi (2016) yaitu Return on Asset (ROA). Sementara itu instrumen variabel dependen komite audit dikembangkan Anggitarani (2009) dengan jumlah rapat komite audit per tahun. Variabel komite pemantau resiko (Hoang, et al., 2017) berupa jumlah pertemuan komite dalam perusahaan di satu tahun periode. 
Variabel komite remunerasi dan nominasi menggunakan instrumen dari Anggraini (2014), serta variabel dewan pengawas syariah menggunakan instrumen dari Umam dan Ginanjar (2020) dan juga Purwanti (2016) yakni jumlah rapat atau frekuensi pertemuan dalam satu tahun.

\section{Analisis Data}

Metode analisis data yang digunakan dalam penelitian ini adalah analisis kuantitatif yang bersifat deskriptif yang menjabarkan data yang diperoleh dengan menggunakan analisis regresi. Metode analisis data ini akan dilakukan dengan bantuan program aplikasi komputer SPSS ver 20.0 .

\section{Analisis Regresi Linear Berganda}

Analisis regresi linear berganda digunakan untuk menganalisis pengaruh lebih dari satu variabel independen terhadap variabel dependen. Secara umum, analisis regresi pada dasarnya adalah studi mengenai ketergantungan variabel dependen (terikat) dengan satu atau lebih variabel independen (variabel penjelas/bebas) dengan tujuan untuk mengestimasi dan/atau memprediksi rata-rata populasi atau nilai rata-rata variabel dependen berdasarkan nilai variabel independen yang diketahui (Ghozali, 2016). Sesuai dengan permasalahan, tujuan, kerangka pemikiran dan pengembangan hipotesis dalam penelitian ini yaitu hipotesis 1 , hipotesis 2 , hipotesis 3 dan hipotesis 4, selanjutnya digunakan model regresi linear berganda pertama sebagai berikut:

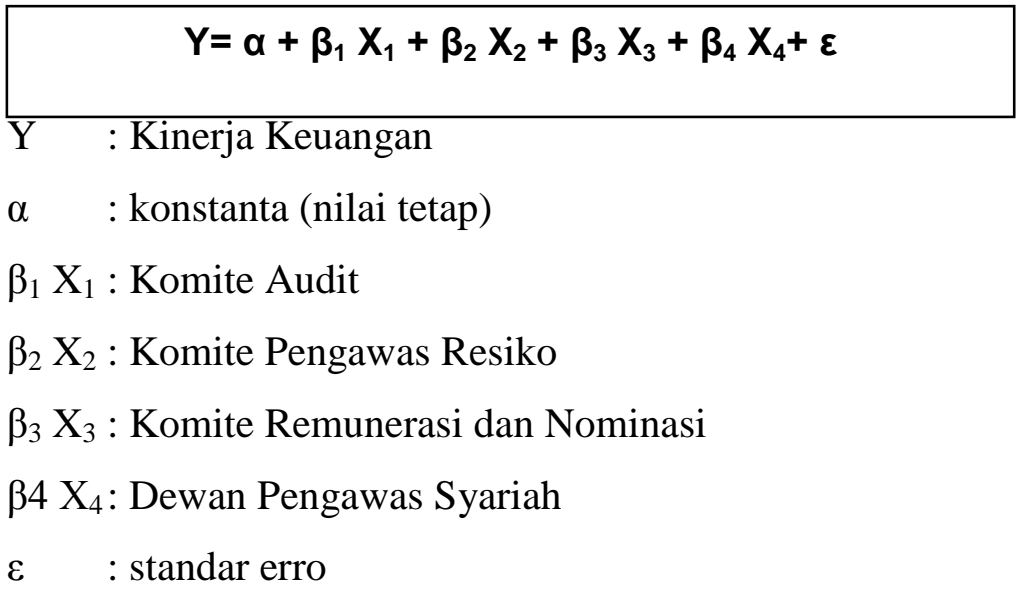

\section{HASIL PENELITIAN DAN PEMBAHASAN}

Menunjuk pada hasil tabel 4.1 diketahui skor ROA berkisar antara -0,2013 sampai dengan 0,5143, mean sebesar 0,077183, std. deviation 0,149697. Komite audit berkisar antara 3 sampai 31, dengan mean sebesar 12,17, dan std. deviation 7,434. Komite pemantau resiko berkisar antara 2 sampai 59, dengan mean sebesar 14,13, dan std. deviation 13.009. 
Komite remunerasi dan nominasi berkisar antara 1 sampai 12, dengan mean sebesar 5,53, dan std. deviation 3,143. Dewan pengawas syariah berkisar antara 3 sampai 32, dengan mean sebesar 13,70, dan std. deviation 6.242.

Berikut hasil statistik deskriptif berdasarkan data yang diperoleh:

\section{Tabel 1}

Hasil Uji Deskriptif

\begin{tabular}{llllll}
\hline Descriptive Statistics & & & & & \\
& N & Minimum & Maximum & Mean & Std. Deviation \\
\hline ROA & 60 &,- 2013 & 0,5143 & 0,0771 & 0,149697 \\
& & & & 8 & \\
Komite Audit & 60 & 3 & 31 & 12,17 & 7,434 \\
Komite Pemantau Resiko & 60 & 2 & 59 & 14,13 & 13,009 \\
Komite Remunerasi dan Nominasi & 60 & 1 & 12 & 5,53 & 3,143 \\
Dewan Pengawas Syariah & 60 & 3 & 32 & 13,70 & 6,242 \\
Valid N (listwise) & 60 & & & & \\
\hline
\end{tabular}

Sumber: Data sekunder yang diolah (2020)

Berdasarkan hasil tersebut diketahui bahwa nilai std. deviation ke 4 variabel lebih kecil dari pada nilai mean. Hal ini menggambarkan hasil yang baik. Standar deviasi menunjukkan penyimpangan dari data variabel tersebut yang nilainya lebih kecil dari nilai rata-ratanya.

\section{Hasil Uji Hipotesis}

Analisis regresi berganda yaitu menganalisis besarnya hubungan pengaruh variabel independen yang jumlahnya lebih dari dua. Analisis regresi berganda merupakan teknik analisis regresi yang dapat digunakan dalam menguji pengaruh beberapa variabel independen terhadap variabel dependen (Latan dan Temalagi, 2013: 84). Berikut ini analisis regresi berganda menggunakan program SPSS versi 20:

Tabel 2

\section{Uji Analisis Regresi Berganda}

\begin{tabular}{|c|c|c|c|c|c|}
\hline & \multicolumn{2}{|c|}{$\begin{array}{c}\text { Unstandardized } \\
\text { Coefficients }\end{array}$} & \multirow{2}{*}{$\begin{array}{l}\text { Standardized } \\
\text { Coefficients } \\
\text { Beta } \\
\end{array}$} & \multirow[b]{2}{*}{$\mathrm{t}$} & \multirow[b]{2}{*}{ Sig. } \\
\hline & B & Std. Error & & & \\
\hline (Constant) &,- 186 & ,027 & & $-6,781$ & ,000 \\
\hline Komite Audit & ,004 & ,002 & 213 & 2,054 & ,045 \\
\hline Komite Pemantau Resiko & ,002 & ,001 & ,216 & 2,116 & ,039 \\
\hline Komite Remunerasi dan Nominasi & ,016 & ,005 & ,332 & 3,494 & ,001 \\
\hline Dewan Pengawas Syariah & ,006 & ,002 & ,269 & 2,842 & ,006 \\
\hline
\end{tabular}

Sumber: Data Olahan Sekunder (2020)

Dari hasil tabel analisis regresi linier berganda di atas diperoleh persamaan yaitu: $\mathrm{Y}=-$ $0,186+0,004 \mathrm{KA}+0,002 \mathrm{KPR}+0,016 \mathrm{KRN}+0,006 \mathrm{DPS}+\mathrm{e}$. Berdasarkan persamaan regresi tersebut dapat diintepretasikan sebagai berikut: 


\section{Hasil Pengujian Hipotesis 1}

Ditunjukkan dengan hasil uji t pada variabel komite audit (X1) mempunyai nilai thitung $(2,054)>\mathrm{t}$ tabel $(2,015)$ dan nilai probabilitas $(0,045)<\alpha(0,05)$. Demikian $\mathrm{H}_{0}$ ditolak dan $\mathrm{H}_{1}$ diterima. Dengan menganggap variabel lainya konstan, sehingga dapat disimpulkan bahwa variabel komite audit berpengaruh secara signifikan terhadap kinerja keuangan (Y).

Hasil dalam penelitian ini menunjukkan bahwa efektifitas komite audit memiliki pengaruh positif terhadap kinerja perbankan syariah di Indonesia tahun 2014-2018. Artinya dengan intensitas rapat komite audit yang meningkat maka hal ini berarti tingkat pengawasan yang dilakukan juga semakin baik. Sehingga dari hasil rapat yang terjadi mampu memberikan output kepada manajerial dalam hal ini dewan direksi terutama pengawasan atas berjalannya good corporate governance melalui pemantauan terhadap Sistem Pengendalian Internal (SPI) perusahaan, sehingga manajemen diharapkan mampu mengelola aset dengan efektif dan efisien sehingga mempengaruhi peningkatan asset perusahaan yang berarti bahwa tingkat kinerja perbankan menjadi lebih baik. Hasil ini sesuai dengan penelitian sesuai dengan penelitian Taufiq, et al. (2014), Arifani (2013) yang menyatakan bahwa komite audit berpengaruh terhadap kinerja keuangan. Hasil ini berbeda dengan penelitian Hartono dan Nugrahanti (2014), Hutami (2014), Fauzi (2016), serta Sulistyowati dan Fidiana (2017) yang menyatakan komite audit tidak berpengaruh terhadap kinerja keuangan.

\section{Hasil Pengujian Hipotesis 2}

Dari hasil uji t pada variabel komite pemantau resiko (X2) mempunyai nilai t hitung $(2,116)>\mathrm{t}$ tabel $(2,004)$ dan nilai probabilitas $(0,039)<\alpha(0,05)$, dengan demikian $\mathrm{H}_{0}$ ditolak dan $\mathrm{H}_{2}$ diterima. Hasil penelitian ini menggambarkan bahwa komite pemantau resiko memiliki pengaruh positif signifikan terhadap kinerja perbankan syariah yang diukur dengan jumlah rapat yang dilaksanakan setiap tahunnya.

Berdasarkan hasil tersebut dapat disimpulkan bahwa efektivitas komite pemantau resiko dengan melalui rapat-rapat yang dilaksanakan menunjukkan hasil berupa rekomendasi terhadap pelaksanaan pengelolaan manajemen resiko oleh manajemen. Selanjutnya manajemen bisa meminimalisir resiko yang akan terjadi pada pengelolaan asset sehingga mempengaruhi kinerja perbankan syariah akan semakin baik. Hasil penelitian ini sama dengan penelitian Widyani (2015) yang menunjukkan bahwa komite pemantau resiko memiliki pengaruh terhadap nilai perusahaan. Berbeda dengan penelitian Hutami (2014) dan juga Faisal dan Dyah (2019) yang menyatakan bahwa komite pemantau resiko tidak memiliki pengaruh terhadap kinerja. 


\section{Hasil Pengujian Hipotesis 3}

Hasil dalam penelitian ini menunjukkan bahwa hasil uji $\mathrm{t}$ pada variabel komite remunerasi dan nominasi (X3) mempunyai nilai t hitung $(3,494)>t$ tabel $(2,004)$ dan nilai probabilitas $(0,01)<\alpha(0,05)$, hal ini berartinya variabel komite remunerasi dan nominasi berpengaruh secara signifikan terhadap kinerja keuangan pada perbankan. Dengan demikian $\mathrm{H}_{0}$ ditolak dan $\mathrm{H}_{3}$. Maka dari hasil tersebut dapat disimpulkan bahwa efektivitas komite remunerasi dan nominasi mampu memberikan output untuk terlaksana dan tercapainya tujuan perusahaan. Sehingga berpengaruh terhadap pengelolaan aset yang berdampak pada kinerja perbankan syariah yang diukur dengan jumlah rapatnya, artinya bahwa dengan adanya keberadaan komite remunerasi dan nominasi ini dapat membantu kerja dewan komisaris dalam melaksanakan fungsi dan tugas dewan komisaris itu sendiri yang berhubungan dengan remunerasi anggota direksi dan anggota dewan komisaris. Penelitian ini sesuai dengan penelitian Widyani (2015) yang menyatakan komite remunerasi dan nominasi berpengaruh signifikan terhadap kinerja Bank. Penelitian ini tidak mendukung penelitian Murwaningsari (2009) yang menyimpulkan bahwa komite nominasi dan remunerasi tidak berpengaruh terhadap nilai perusahaan.

\section{Hasil Pengujian Hipotesis 4}

Hasil uji t pada variabel dewan pengawas syariah (X4) mempunyai nilai t hitung $(2,127)$ $>\mathrm{t}$ tabel $(2,004)$ dan nilai probabilitas $(0,006)<\alpha(0,05)$, dengan demikian $\mathrm{H}_{0}$ ditolak dan $\mathrm{H}_{4}$. Artinya variabel dewan pengawas syariah memiliki pengaruh secara signifikan kepada kinerja keuangan pada perbankan syariah di Indonesia periode 2014-2018.

Peneliltian ini menunjukkan efektifitas dewan pengawas syariah menjalankan tugasnya dalam pengawasan terhadap operasional perusahaan melalui rapat-rapat intens mampu berikan dampak kepada pengeloalaan aset. Penelitian ini sejalan dengan penelitian Ramiz dan Mangla (2010), Hisamuddin dan Tirta (2011) yang menunjukkan pengaruh positif dewan pengawas syariah terhadap kinerja. Namun berbeda dengan penelitian Fauzi (2016) yang menjelaskan bahwa dewan pengawas syariah tidak berpengaruh signifikan terhadap kinerja keuangan.

\section{Koefisien Determinasi (Adjusted $R^{2}$ )}

Koefisien determinasi adalah sebuah koefisien yang menunjukkan persentase semua pengaruh variabel independen terhadap variabel dependen.Persentase tersebut menunjukkan seberapa besarnya variabel independen dan variabel moderating dapat menjelaskan variabel dependen. Berikut adalah tabel hasil uji koefisien determinasi: 


\section{Tabel 3}

\section{Hasil Uji Koefisien Determinasi $\left(\mathbf{R}^{2}\right)$}

\begin{tabular}{lcrrrr}
\hline \multicolumn{5}{c}{ Model Summary $^{\mathbf{b}}$} \\
\hline Model & $\mathrm{R}$ & R Square & Adjusted R Square & $\begin{array}{c}\text { Std. Error of the } \\
\text { Estimate }\end{array}$ & Durbin-Watson \\
\hline 1 & $0,847^{\mathrm{a}}$ & 0,717 & 0,697 & 0,0824224 & 1,732 \\
\hline
\end{tabular}

Sumber: Data Sekunder yang diolah (2020)

Dari Tabel 4.6 di atas menunjukkan bahwa nilai R Square yaitu 0,717. Artinya adalah bahwa sumbangan pengaruh variabel X1, X2, X3, X4 terhadap Y adalah sebesar 72\% Sedangkan sisanya $28 \%$ dipengaruhi oleh variabel lain yang tidak terdapat pada model penelitian ini.

\section{SIMPULAN}

Berdasarkan data dan hasil penelitian yang dilakukan serta pembahasan sebagaimana yang dijelaskan bahwa keberadaan variable-variabel mekanisme internal yakni: komite audit, komite pemantau resiko, komite remunerasi dan nominasi yang wajib dibentuk oleh Dewan Komisaris guna mendukung efektivitas pelaksanaan tugas dan tanggungjawabnya (POJK 55, 2016) ditambah variabel dewan pengawas syariah, memberikan pengaruh kepada peningkatan kinerja perusahaan.

Peneliti menyadari bahwa penelitian ini tidak terlepas dari keterbatasan yang dimiliki, namun demikian diharapkan mampu memberikan bahan pertimbangan dalam praktek dan pengembangan berikutnya, beberapa keterbatasan penelitian ini antara lain: penelitian ini terbatas pada empat variabel mekanisme good corporate governance, sementara masih terdapat variabel-variabel lain dari mekanisme good corporate governance (internal maupun external) yang bisa saja mempengaruhi kinerja perbankan syariah. Selanjutnya, sampel penelitian ini terbatas pada 12 Bank Umum Syariah di Indonesia dan hanya menggunakan lima tahun periode yaitu tahun 2014-2018.

Good Corporate Governance merupakan hal yang sangat dibutuhkan dan diwajibkan regulator bagi perusahaan yang sudah go public. Keberadaanya mampu memberikan dampak yang positif guna mengatasi masalah-masalah yang kompleks dari suatu perusahaan. Berdasarkan penelitian yang di atas dapat kami sarankan yaitu: Selain mekanisme internal variable mekanisme external seperti Kantor Akuntan Publik dapat dijadikan variabelnya terhadap kinerja karena juga merupakan faktor penting sebagai bagian mewujudkan kinerja yang baik bagi suatu perusahaan. Kemudian, mekanisme eksternal yang lain yaitu regulator, dalam hal ini adalah POJK tentang GCG, dapat menjadi sebagai salah satu sebagai variable dalam penelitiannya, karena sebagai pihak luar yang memiliki fungsi yang dibutuhkan dalam mewujudkan kinerja yang baik. 


\section{REFERENSI}

Anggitarani, A. (2009). Pengaruh Corporate Governance, Etnis Latar Belakang Pendidikan Terhadap Kinerja Keuangan Perusahaan: Studi Empiris Pada Perusahaan Publik yang Terdaftar di BEI. Universitas Sebelas Maret.

Anggraini. (2014). Pengaruh Good Corporate Governance dan Earning Power Terhadap Manjemen Laba (Studi Empiris Pada Perusahaan yang Terdaftar di BEI 2009-2013), Jurnal FEB. Unipad.

Arifani, Rizky. (2013). Pengaruh Good Corporate Governance Terhadap Kinerja Keuangan Perusahaan. Universitas Brawijaya.

Bank Indonesia. (2009). Peraturan Bank Indonesia Nomor 11/33/PBI/2009 tentang Pelaksanaan Good Corporate Governance bagi Bank Umum Syariah dan Unit Usaha Syariah, Jakarta.

CNBCindonesia.com. (2019). Perbankan Syariah Masih Sulit Bersaing dengan Konvensional, https://www.cnbcindonesia.com/syariah/20190607133414-29-77037/perbankansyariah-masih- sulit-bersaing-dengan-konvensional. Diakses tgl 2 April 2020.

Effendi, M. A. (2016). The Power of Good Corporate Governance. Edisi 2. Jakarta: Salemba Empat.

Erfina. (2014). Pengaruh Good Corporate Governance Terhadap Kinerja Keuangan Perbankan Syariah di Indonesia. Artikel Publikasi Ilmiah. Universitas Muhammadiyah Surakarta. Surakarta.

Fahmi, I. (2012). Analisis Kinerja Keuangan, Alfabeta, Bandung.

Faisal, dan Ismoyorini, N. I. D. (2019). Pengaruh Tata Kelola Risiko Terhadap Kinerja Perusahaan. Jurnal Penelitian Ekonomi dan Bisnis, 4 (2), 2019, Hal: 180-191, Universitas Diponegoro.

FCGI. (2003). Seri Tata Kelola Perusahaan (Corporate Governance) Jilid II. FCGI: Jakarta.

Finansial.bisnis.com. (2019). Rapor Bank Syariah Masih Merah. (https://finansial.bisnis.com/read/20191104/90/1166469/raporbanksyariah-masihmerah). Diakses pada tanggal 27 Februari 2020.

Ghozali, Imam. 2013. Aplikasi Analisis Multivariate dengan Program IBM SPSS 21. Semarang: Badan Penerbit Universitas Diponegoro.

Hartono, D. F., dan Nugrahanti, Y. W. (2014). Pengaruh Mekanisme Corporate Governance Terhadap Kinerja Keuangan Perusahaan Perbankan. Artikel Unisbank, Vol 3 No 2 (2014).

Hisamuddin, N dan Tirta K, M. Y. (2011). Pengaruh Good Corporate Governance Terhadap Kinerja Keuangan Bank Umum Syariah. Jurnal Akuntansi, Universitas Jember. Jember. 
Hoang Ha, et al. (2017). The Sharing Economy And Collaborative Finance: The Case of P2P Lending in Vietnam. Jurnal Ekonomi Bisnis Vol 22 No.2.

Hutami, T. R. K., dan Marsono. M. (2014). Pengaruh Mekanisme Corporate Governance terhadap Kinerja Keuangan Perbankan. (Studi Kasus Pada Bank Pembangunan Daerah di Indonesia Periode 2010-2013). Diponegoro Journal of Accounting.

Kasmir. (2016). Analisis Laporan Keuangan. Jakarta: RajaGrafindo Persada.

Komite Nasional Kebijakan Governance. (2012). Prinsip Dasar Pedoman Good Corporate Governance Perbankan Indonesia. Jakarta.

Kompasiana.com. (2019). Kecurangan (Fraud) yang Bisa Meruntuhkan Perbankan Syariah, https://www.kompasiana.com/alihozi77.blogspot.com

5a9b6337f13344531e1f2163/kecurangan-fraud-yang-bisa-meruntuhkan-perbankansyariah- diakses tanggal 2 April 2020.

Latan, H., dan Temalagi, S. (2013). Analisis Multivariate Teknik dan Aplikasi Menggunakan Program IBM SPSS 20,0. Bandung: Penerbit Alfabeta.

Lestari, Y.T, dan Asyik, N. F. (2015). Pengaruh Corporate Governance Terhadap Kinerja Keuangan: Corporate Social Responsibility Sebagai Variabel Intervening. Jurnal Imu \& Riset Akuntansi, Vol 4 No 7.

Mas'ul T., Lubis, A. F., dan Mulyani, S. (2014). Pengaruh Penerapan Good Corporate Governance Terhadap Kinerja Keuangan dengan Menggunakan Manajemen Laba Sebagai Variabel Intervening. Jurnal Telaah dan Riset Akuntansi, Vol 7 No 1 Hlm. 6675.

Mohammed, Fatimoh. (2012). Impact of Corporate Governance on Banks Performance in Nigeria. Journal of Emerging Trends in Economics and Management Sciences. Vol. 3. Issue 3 Pages 257-260. Nigeria.

Munawir, S. 2000. Analisis Laporan Keuangan. Yogyakarta: Liberty.

Murwaningsari, E. (2009). Hubungan Corporate Governance, Corporate Social Responsibilities dan Corperate Financial Performance dalam Satu Continuum. Jurnal Akuntansi dan Keuangan. Vol 11, No.1, Mei 2009: 30-41. 129.

Nur DP, E. 2012. Agency Theory \& Corporate Governance. Pekanbaru: Pusat Pengembangan Pendidikan Universitas Riau.

Otoritas Jasa Keuangan. (2014). Peraturan Otoritas Jasa Keuangan (POJK) Nomor 8/POJK.03/2014 tentang Penilaian Tingkat Kesehatan Bank Umum Syariah dan Unit Usaha Syariah. Jakarta.

Otoritas Jasa Keuangan. (2016). Peraturan Otoritas Jasa Keuangan (POJK) Nomor 55/POJK.03/2016 tentang Penerapan Tata Kelola Bagi Bank Umum. Jakarta.

Otoritas Jasa Keuangan. (2017). Peraturan Otoritas Jasa Keuangan (POJK) Nomor 59/POJK.03/2017 tentang Penerapan Tata Kelola Dalam Pemberian Remunerasi Bagi Bank Umum Syariah dan Unit Usaha Syariah. Jakarta. 
Purwanti, A. (2016). Dewan Pengawas Syariah dan Pengungkapann Aspek Lingkungan, Produk Dan Jasa Pada Banknn Syariah. Jurnal Akuntansi dan Keuangan Islam. Fakultas Ekonomi Universitas Islam As-Syafi'iyah. Vol. 4, No. 2.

Rahmawati, N. B., dan Handayani, R. S. (2017). Analisis Pengaruh Karakteristik Corporate Governance Terhadap Kinerja Perusahaan (Studi Empiris Pada Perusahaan Manufaktur yang Terdaftar di Bursa Efek Indonesia Periode 2010-2014). Diponegoro Journal of Accounting, Vol. 6, Nomor 3. Semarang.

Rezaee, Z. (2009). Corporate Governance and Ethics. John Wiley \& Sons, Inc.

Rudianto. (2013). Akuntansi Manajemen Informasi untuk Pengambilan Keputusan Strategis. Jakarta: Erlangga.

Setyawati, V. Y., dan Hudayati, A. (2019). Pengaruh Komite Remunerasi dan Peraturan Otoritas Jasa Keuangan Terhadap Kinerja Perusahaan, Jurnal Universitas Islam Indonesia., Volume 1, Hal. 22-33.

Sulistyowati, dan Fidiana. (2017). Pengaruh Good Corporate Governance Terhadap Kinerja Keuangan Pada Perusahaan Perbankan. Jurnal Ilmu dan Riset Akuntansi. Vol 6, No. 1.

Umam, M. F. S., dan Ginanjar, Y. (2020). Pengaruh Dewan Pengawas Syariah dan Proporsi Dewan Komisaris Independen Terhadap Kinerja Keuangan Perbankan Syariah Indonesia. Jurnal Ekonomi Syariah dan Bisnis. Fakultas Ekonomika dan Bisnis Universitas Majalengka, Vol. 3 No. 1.

Ur Rehman, R., dan Mangla, I. U. (2010). Corporate Governance and Performance of Financial Institutions in Pakistan: A Comparison between Conventional and Islamic Banks in Pakistan. The Pakistan Development Review, Pakistan Institute of Development Economics, vol. 49 (4), pages 461-475.

Widyani, I. P. (2015). Pengaruh Good Corporate Governance terhadap Kinerja Bank Pembangunan Daerah di Indonesia. Tesis. UNS-Pascasarjana Prodi. AkuntansiS4311056-2015. Surakarta.

Zakaria, A. (2018). The Influence of the Audit Committee and the Remuneration Committee on Company Performance. International Conference on Islamic Finance, Economics and Business (ICIFEB, 18-32). 